\title{
Evaluasi Penggunaan Antibiotik Infeksi Saluran Pernapasan Atas pada Anak di Puskesmas Olak Kemang Kota Jambi Tahun 2018
}

\section{Evaluation of Antibiotic Use for Upper Respiratory Tract Infections in Children in Olak Kemang Public Health Center, Jambi in 2018}

\author{
Rasmala Dewi, Deny Sutrisno, Fhatia Medina* \\ Program Studi Farmasi, STIKES Harapan Ibu, Jambi \\ Jl. Tarmizi Kadir No.71, Pakuan Baru, Kecamatan Jambi Selatan, Kota Jambi, \\ Jambi 36122, Indonesia \\ *Corresponding author email: fhatiamedina7796@gmail.com
}

Received 09-03-2020 Accepted 23-06-2020 Available online 01-07-2020

\begin{abstract}
ABSTRAK
Prevalensi penyakit ISPA (Infeksi Saluran Pernapasan Atas) tahun 2018 di Provinsi Jambi sebesar 5,5\%. Hal ini berdampak pada meningkatnya kunjungan berobat ke Puskesmas dan penggunaan obat, salah satunya antibiotik. Hasil survey di Puskesmas Olak Kemang, Kota Jambi menunjukkan masih ada ketidakrasionalan dalam penggunaan antibiotik pada penderita ISPA, khususnya pada anak. Penelitian ini bertujuan untuk mengevaluasi karakteristik demografi, pola, dan kerasionalan penggunaan antibiotik pada anak di Puskesmas Olak Kemang, Kota Jambi Tahun 2018. Sampel dalam penelitian yaitu anak berusia 5-11 tahun, yang didapat dari data register harian dan data sekunder berupa rekam medik dan resep obat. Pengambilan data secara retrospektif, dan data dianalisis dengan kriteria kerasionalan penggunaan obat yang disesuaikan dengan acuan Pharmaceutical Care untuk infeksi saluran pernapasan. Terdapat 70 kasus anak yang didiagnosis ISPA, dengan penggunaan antibiotik terbesar berupa amoksisilin (88,5\%). Kerasionalan penggunaan antibiotik, meliputi parameter ketepatan indikasi, ketepatan pasien, ketepatan obat, ketepatan dosis berdasarkan frekuensi pemberian, dan durasi pemberian, masing-masing dengan skor 100; 98,5; 54,2; 48,5; dan 1,4\%. Dapat disimpulkan bahwa kerasionalan penggunaan antibiotik pada anak di Puskesmas Olak Kemang, Kota Jambi untuk diagnosis ISPA, dari empat parameter ketepatan hanya ketepatan indikasi yang dinilai sudah rasional.
\end{abstract}

Kata kunci: anak, ISPA, kerasionalan, penggunaan antibiotik.

\section{ABSTRACT}

The prevalence of acute respiratory tract infections (ARI) in Jambi Province in 2018 is $5.5 \%$, which subsequently increased medical visits to community health centers and the 
use of drugs, included antibiotics. The survey on Olak Kemang Health Center in Jambi resulted in the finding there were irrationalities in the use of antibiotics in patients with $A R I$, especially in children. This study aims to evaluate the demographic characteristics, patterns, and rationality of antibiotic use in children at the Olak Kemang Health Center in Jambi in 2018. The samples in this study were children aged 5-11 years, in which their data were obtained from the daily data register and secondary data (medical records and prescription of drugs). Data were collected retrospectively and analyzed according to the criteria for rational use of drugs and adjusted to the Pharmaceutical Care reference for respiratory infections. The results showed there were 70 cases of children diagnosed with ARI, with amoxicillin as the most commonly used one (88.5\%). The rationality of antibiotic uses, i.e., indication accuracy, patient accuracy, drug accuracy, dose accuracy based on the frequency of administration, and duration of administration were found to have scores of 100, 98.5, 54.2, 48.5, and 1.4\%, respectively. It can be concluded that the rationality of the use of antibiotics in children diagnosed with ARI at the Olak Kemang Community Health Center in Jambi City, out of four parameters of accuracy, only the accuracy of indication that is considered rational.

Keywords: antibiotic use, ARI, children, rationality.

\section{Pendahuluan}

Infeksi Saluran Pernapasan Atas

(ISPA) merupakan suatu penyakit menular dimana penyakit ini dapat menyerang semua umur dan masih menjadi masalah kesehatan baik di negara maju maupun negara berkembang. Di Indonesia menurut hasil Riset Kesehatan Dasar (Riskesdas) pada tahun 2018, persentase prevalensi penyakit ISPA seluruh provinsi di Indonesia sebesar 9,3\%, salah satunya yaitu Provinsi Jambi dengan persentase 5,5\%. Dari data Dinas Kesehatan Provinsi Jambi pada tahun 2016 diketahui penyakit ISPA termasuk dalam 10 penyakit terbesar di Kota Jambi.

Dari tingginya prevalensi penyakit ISPA hingga berdampak pada meningkatnya kunjungan pasien di sarana pelayanan kesehatan pada tahun 2008 yaitu sebanyak 40-60\% kunjungan berobat di Puskesmas dan $15-30 \%$ kunjungan berobat di rawat jalan dan rawat inap rumah sakit (Kemenkes RI, 2011). Dari segi penggunaan obat juga meningkat seperti penggunaan obat bebas (anti influenza, obat batuk, multivitamin) dan penggunaan antibiotik (Depkes RI, 2005). Berdasarkan hal tersebut ketidakrasionalan dalam penggunaan obat-obatan terutama antibiotik masih sering terjadi pada penderita infeksi saluran pernapasan atas khususnya pada anak maupun balita (Depkes RI, 2005).

Menurut penelitian sejenis yang telah dilakukan Nisa (2017) dengan judul "Evaluasi Penggunaan Antibiotik Infeksi Saluran Pernapasan Atas (ISPA) Anak di Instalasi Rawat Jalan RSUD Dr. Moewardi tahun 2015" menyatakan bahwa penggunaan obat antibiotik untuk kasus ISPA yang meliputi parameter tepat indikasi sebesar $100 \%$, tepat pasien sebesar $100 \%$, tepat obat sebesar $100 \%$, 
ketepatan dosis yang meliputi tepat besaran dosis, tepat frekuensi, tepat rute dan tepat lama pemberian diperoleh hasil tepat obat 15 kasus $(31,9 \%)$ dan tidak tepat obat 32 kasus (68,1\%). Kerasionalan penggunaan antibiotik pada penyakit ISPA anak di instalasi rawat jalan RSUD Dr. Moewardi tahun 2015 sesuai parameter yaitu 15 pasien dengan persentase $(31,9 \%)$ (Nisa, 2017).

Dari survey yang telah dilakukan, terdapat 20 Puskesmas yang ada di Kota Jambi, salah satunya yaitu Puskesmas Olak Kemang. Puskesmas ini terletak di Kawasan Seberang, Kecamatan Danau Teluk, Kota Jambi dan termasuk fasilitas kesehatan dengan jumlah pasien ISPA terbanyak di kota Jambi. Diketahui jumlah pasien ISPA pada tahun 2017 dan 2018 didominasi oleh kelompok anak dan balita dengan jumlah pasien balita berusia 1-5 tahun sebanyak 602 dan pasien anak yang berusia $>5$ tahun sebanyak 1.309. Dari uraian tersebut, peneliti ingin mengevaluasi bagaimana ketepatan penggunaan obat antibiotik pada pasien ISPA khususnya pada anak di Puskesmas Olak Kemang, Kota Jambi tahun 2018.

\section{Metode Penelitian}

\section{Lokasi dan Waktu Penelitian}

Penelitian ini dilaksanakan pada bulan Desember 2019 - Januari 2020 di ruangan rekam medik Puskesmas Olak Kemang, Kota Jambi. Penelitian ini termasuk dalam jenis penelitian noneksperimental dan menggunakan rancangan penelitian deskriptif, teknik pengambilan sampel dengan teknik Purposive sampling (Sani, 2016). Pengambilan data dilakukan secara retrospektif yaitu dengan melakukan penelusuran dokumen terdahulu yang diambil dari rekam medik pasien pada periode tertentu (Notoatmodjo, 2010).

Populasi dan Sampel

Populasi didapatkan dari data register harian lalu ditelusuri data sekunder berupa rekam medik pasien. Data yang diambil selama periode tahun 2018. Teknik pengambilan sampel dengan teknik Purposive sampling yaitu berdasarkan karakteristik yang sudah ditentukan atau diinginkan (Sani, 2016). Sampel berupa data rekam medik pasien anak yang didiagnosis ISPA di Puskesmas Olak Kemang yang memenuhi kriteria sampel sebagai berikut, (a) pasien anak berusia 5-11 tahun sesuai dengan kategori umur menurut Depkes RI tahun 2009 dan (b) pasien anak dengan kunjungan berobat selama periode tahun 2018 yang didiagnosis ISPA dan mendapatkan antibiotik.

Data yang akan diambil pada rekam medik meliputi jenis kelamin pasien, umur pasien, berat badan pasien, diagnosa penyakit pasien, golongan antibiotik, jenis antibiotik, sediaan dan dosis obat, serta frekuensi dan lama pemberian. Kemudian dilakukan analisis kerasionalan penggunaan antibiotik yang meliputi analisis tepat indikasi, tepat pasien, tepat obat, dan tepat dosis lalu membandingkan dengan pedoman yang dijadikan acuan. 
Instrumen Penelitian

Instrumen yang digunakan adalah lembar pengumpulan data. Acuan pengobatan berdasarkan Pharmaceutical care untuk penyakit Infeksi Saluran Pernapasan (Depkes RI, 2005).

\section{Pengolahan dan Analisis Data}

$$
\text { Berdasarkan data yang }
$$

didapatkan, lalu dianalisis menggunakan analisis deskriptif, dikaji gambaran karakteristik demografi pasien berdasarkan jenis kelamin, pola penggunaan antibiotik yang meliputi golongan dan jenis antibiotik yang didapatkan pasien anak dengan ISPA lalu dihitung tingkat kerasionalannya berdasarkan kriteria 4T yakni; (1) Tepat indikasi, yaitu melihat kesesuaian pemberian antibiotik yang diberikan dengan diagnosa yang didapatkan. (2) Tepat pasien, yaitu melihat kesesuaian kontraindikasi antibiotik dengan keadaan kondisi klinis pasien. Pertama, melihat riwayat penyakit yang tertera dalam rekam medik, lalu umur dan berat badan pasien apakah berpengaruh terhadap kerja obat. Kedua, disesuaikan dengan beberapa panduan atau buku seperti, ISO Farmakoterapi. (3) Tepat obat, yaitu membandingkan pemberian antibiotik pada rekam medik dan resep obat dengan standar pharmaceutical care untuk Infeksi Saluran Pernapasan tahun 2005. (4) Tepat dosis, yaitu membandingkan dosis, frekuensi dan durasi antibiotik pada rekam medik dengan dosis yang sesuai dengan standar pharmaceutical care untuk Infeksi Saluran Pernapasan tahun 2005.

$$
\text { Persentase penggunaan }
$$

antibiotik pada pasien anak yang di diagnosis ISPA yang mendapatkan antibiotik dihitung dengan menggunakan rumus 1-6. Hasil data di sajikan dalam bentuk tabel.

Persentase karakteristik demografi pasien berdasarkan jenis kelamin, yaitu laki-laki dan perempuan:

Demografi pasien $=\frac{\text { jumlah } \text { pasien pada setiap kelompok jenis kelamin }}{\text { jumlah pasien secara keseluruhan }} \times 100$

Persentase pola penggunaan antibiotik yang meliputi golongan dan jenis antibiotik:

Pola penggunaan $=\frac{\text { Jumlah } \text { kasus tiap golongan dan jenis antibiotik }}{\text { Jumlah total kasus }} \times 100$

Persentase kerasionalan penggunaan obat kriteria 4T yang meliputi:

Ketepatan indikasi $=\frac{\text { Jumlah } \text { kasus yang tepat indikasi }}{\text { Jumlah total kasus }} \times 100$

Ketepatan pasien $=\frac{\text { Jumlah } \text { kasus } y \text { ang tepat pasien }}{\text { Jumlah total kasus }} \times 100$

Ketepatan obat $=\frac{\text { Jumlah } \text { kasus yang tepat obat }}{\text { Jumlah total } \text { kasus }} \times 100$ 
Ketepatan dosis $=\frac{\text { Jumlah } \text { kasus yang tepat dosis }}{\text { Jumlah total } \text { kasus }} \times 100$

\section{Hasil dan Pembahasan}

Hasil penelitian didapatkan bahwa ada 160 pasien anak yang didiagnosis ISPA di Puskesmas Olak Kemang selama tahun 2018. Namun, yang termasuk dalam kriteria sampel yaitu sebanyak 70 pasien anak dengan rentang usia 5-11 tahun sesuai kategori umur menurut Depkes RI tahun 2009.

\section{Karakteristik} demografi menunjukkan bahwa dari 70 pasien anak, 41 di antaranya didominasi oleh pasien laki-laki dengan persentase sebesar 58,5\% dan 29 di antaranya adalah pasien perempuan dengan persentase $41,4 \%$ (Tabel 1). Hal ini juga didukung oleh hasil penelitian yang telah dilakukan Suyami \& Sunyoto (2006) bahwa faktor anak laki-laki lebih banyak terkena ISPA dikarenakan anak laki-laki biasanya lebih aktif dan suka melakukan aktivitas bermain di luar rumah, berkumpul di tempat yang lingkungannya kotor, berdebu, sehingga tubuh akan kontak langsung dengan partikel udara dan agen penyakit. Penelitian lain juga menyatakan bahwa di Poliklinik anak RSUP DR. M. Djamil Padang pada tahun 2012-2013 kejadian ISPA lebih sering terjadi pada anak lakilaki dengan persentase sebesar $54,7 \%$ sedangkan perempuan $45,3 \%$ (Maharani et al., 2017).
Pada beberapa penelitian juga setelah dilakukan uji chi-kuadrat diperoleh nilai $p=0,002$, dimana menunjukkan hubungan yang bermakna antara jenis kelamin dan kejadian ISPA. Anak laki-laki diketahui lebih beresiko terkena ISPA sebanyak 1.839 kali dibandingkan perempuan, nilai koefisien phi sebesar 0,263 yang menyatakan bahwa jenis kelamin mempunyai korelasi derajat lemah dengan kejadian ISPA pada anak usia 1-5 tahun (Iskandar et al., 2015).

Pembagian usia berdasarkan fase perkembangan anak menurut Charlotte Buhle disajikan pada Tabel 2. Rata-rata penyakit ISPA pada anak terjadi pada rentang usia 5-8 tahun dengan persentase $77,1 \%$, yang didominasi anak berusia 5 tahun. Pada usia 9-11 tahun persentase hanya $22,8 \%$. Pada usia 5-8 tahun merupakan masa perkembangan anak mulai melakukan sosialisasi dan memasuki masyarakat luas (misalnya taman kanak-kanak, pergaulan dengan teman sepermainan, dan sekolah rendah). Anak mulai belajar mengenal dunia belajar secara obyektif dan rasa ingin tahu terhadap aktifitas di dunia luar, sehingga memungkinkan anak terpapar oleh debu dan polusi pada saat bermain dan kontak dengan penderita ISPA (Setiyaningrum, 2017). 
Vol.17 No. 01 Juli 2020:158-171

Tabel 1. Karakteristik demografi jumlah pasien berdasarkan jenis kelamin

\begin{tabular}{lcc}
\hline Jenis Kelamin & Jumlah Pasien & Persentase (\%) \\
\hline Laki-laki & 41 & 58,5 \\
Perempuan & 29 & 41,4 \\
\hline Total & 70 & 100 \\
\hline
\end{tabular}

Tabel 2. Karakteristik demografi jumlah pasien berdasarkan usia (Setiyaningrum, 2017)

\begin{tabular}{lcc}
\hline Usia & Jumlah Pasien & Persentase (\%) \\
\hline 5-8 tahun (masa sosialisasi anak) & 54 & 77,1 \\
9-11 tahun (masa sekolah rendah) & 16 & 22,8 \\
\hline Total & 70 & 100 \\
\hline
\end{tabular}

\begin{tabular}{|c|c|}
\hline \multirow{2}{*}{$\begin{array}{l}\text { Beberapa penelitian juga } \\
\text { menyatakan bahwa mekanisme }\end{array}$} & ayi. Diperoleh nilai p value $=0,014$ \\
\hline & $\mathrm{OR}=2,160$ \\
\hline hubungan usia dengan kejadian ISPA & disimpulkan bahwa ada pengar \\
\hline sebabkan karena faktor imunitas yang & bermakna \\
\hline erbentuk secara sempu & SPA. Anak \\
\hline $\begin{array}{l}\text { emiliki sel } T \text { yang tinggi dan masih } \\
\text { erbentuk naïf, sel tersebut tidak }\end{array}$ & $\begin{array}{l}\text { terkena ISPA dibandingkan bayi } \\
\text { et al., 2014). }\end{array}$ \\
\hline $\begin{array}{l}\text { berespon terhadap suatu paparan } \\
\text { antigen tertentu salah satunya jika } \\
\text { terjadi infeksi, biasanya paparan yang }\end{array}$ & $\begin{array}{l}\text { Penularan maupun penyeb } \\
\text { Infeksi melalui saluran pernap } \\
\text { sangat mudah terjadi melalui batuk }\end{array}$ \\
\hline & bersin yang membentuk $p$ \\
\hline $\begin{array}{l}\text { luran pernapasan. Hal inilah yang } \\
\text { enyebabkan anak banyak mengalami }\end{array}$ & $\begin{array}{l}\text { infeksius di udara dan berpinda } \\
\text { orang sakit ke orang yang b }\end{array}$ \\
\hline $\begin{array}{l}\text { PA terlebih dahulu (Iskandar et al., } \\
\text { 015). }\end{array}$ & $\begin{array}{l}\text { tertular atau dapat melalui kol } \\
\text { langsung. Oleh sebab itu, balita }\end{array}$ \\
\hline $\begin{array}{l}\text { Penelitian lain juga menyatakan } \\
\text { lari hasil uji statistik antara pengaruh } \\
\text { Isia anak dengan kejadian ISPA } \\
\text { liperoleh bahwa usia balita lebih }\end{array}$ & $\begin{array}{l}\text { beresiko tertular ISPA karena } f \\
\text { kekebalan tubuh juga disebr } \\
\text { karakteristik perkembangan yang }\end{array}$ \\
\hline
\end{tabular}

Tabel 3. Pola penggunaan antibiotik di Puskesmas Olak Kemang tahun 2018

\begin{tabular}{lcccc}
\hline No. & Jenis Antibiotik & Golongan Antibiotik & Jumlah Kasus & Persentase (\%) \\
\hline 1. & Amoksisilin & Penisilin & 62 & 88,5 \\
2. & Eritromisin & Makrolida & 5 & 7,1 \\
3. & Cefadroxil & Sefalosporin & 2 & 2,8 \\
4. & Ciprofloxacin & Kuinolon & 1 & 1,4 \\
\hline Total & & & 70 & 100 \\
\hline
\end{tabular}


Dari hasil rekam medik Puskesmas Olak Kemang pada tahun 2018, diketahui bahwa penggunaan antibiotik yang banyak digunakan pada anak untuk ISPA yaitu jenis antibiotik amoksisilin dari golongan penisilin dengan persentase yaitu sebesar (88,5\%), lalu eritromisin $(7,1 \%)$ dari golongan makrolida, cefadroxil $(2,8 \%)$ dari golongan sefalosporin, dan ciprofloxacin (1,4\%) dari golongan kuinolon (Tabel 3).

Kerasionalan penggunaan antibiotik berdasarkan indikasi disajikan pada Tabel 4. Berdasarkan evaluasi ketepatan indikasi dimana pemilihan obat harus disesuaikan dengan kondisi pasien dan didasari oleh diagnosa yang ditegakkan dokter. Dokter juga berperan dalam mengevaluasi apakah pasien memerlukan terapi menggunakan antibiotik atau tidak. Dari hasil didapatkan bahwa penggunaan antibiotik untuk pasien ISPA sudah tepat indikasi dan penggunaannya, seharusnya dalam pemilihan penggunaan antibiotik hanya dapat dilakukan jika sudah mengetahui bakteri penyebab yang paling memungkinkan dan pola sensitifitas. Dengan mengetahui pola bakteri pada kultur dan sensitifitasnya terhadap antibiotic, maka pemilihan terapi empirik dapat ditentukan.

\section{Pengidentifikasian}

bakteri patogen penyebab infeksi perlu dilakukan terlebih dahulu lalu dilanjutkan dengan kultur dan uji kepekaan (sensitifitas) terhadap antibiotik (Katarnida et al., 2016). Sedangkan, di Puskesmas Olak Kemang sendiri, pemberian antibiotik tidak didasari dengan uji kultur terlebih dahulu, hanya berdasarkan diagnosa dokter dan kondisi pasien pada saat itu. Pada kasus faringitis, pemberian antibiotik jika pasien menunjukkan gejala klinis seperti batuk berdahak yang disertai demam lalu nyeri pada tenggorokan, nyeri pada saat menelan, sakit kepala hingga eksudat yang purulen dan disertai peradangan hingga lebih dari 3 hari (Depkes RI, 2005). Pada kasus otitis media pemberian antibiotik biasanya dipilih jika sudah menunjukkan gejala klinis seperti adanya peradangan lokal pada telinga, keluarnya cairan dari telinga, kurangnya pendengaran, berkurangnya nafsu makan, dan disertai demam (Depkes RI, 2005).

Pemberian antibiotik pada kasus tonsilitis tanda dan gejala sudah menunjukkan adanya bakteri. Gejala klinis yang biasanya dirasakan seperti nyeri tenggorokkan, kesulitan dalam menelan, dan dirasakan berulang atau menetap, dan biasanya disertai demam. Hal ini terjadi dikarenakan adanya kuman yang menempel pada bagian tonsil, kuman ini biasanya didapatkan melalui hidung pada saat bernapas maupun secara foodborn yaitu melalui mulut bersama dengan makanan (Ramadhan et al., 2017). Pada keadaan inilah fungsi pertahanan tubuh terganggu dikarenakan tonsil menjadi tempat bersarangnya bakteri, lama kelamaan tentu akan menyebabkan respon imun menurun dan tubuh menjadi terinfeksi.

Ketepatan pasien dievaluasi 
yaitu melihat apakah ada atau tidaknya kontraindikasi obat dengan kondisi pasien (Tabel 5). Pada penelitian ini, jenis antibiotik amoksisilin, eritromisin, dan cefadroksil sudah memenuhi kriteria tepat pasien dengan persentase ketepatan sebesar 98,5\% dan hanya antibiotik ciprofloksasin yang tidak memenuhi kriteria tepat pasien dengan persentase $1,4 \%$. Kurangnya informasi yang tertera pada rekam medik menjadi kendala dalam evaluasi ini, seperti alergi obat dan hanya sebagian yang menuliskan riwayat penyakit pasien.

Amoksisilin banyak menjadi pilihan dalam terapi infeksi saluran pernapasan karena termasuk dalam antibiotik berspektrum luas sehingga untuk terapi empiris antibiotik ini dinilai efektif. Amoksisilin memiliki kontraindikasi jika pasien hipersensitivitas terhadap penisilin. Untuk antibiotik dari golongan berbeda namun spektrum antibakteri hampir sama dengan penisilin yaitu eritromisin dimana eritromisin tidak dapat diberikan pada pasien yang mempunyai penyakit hati (garam estolat) atau ganggguan fungsi hati dan gagal ginjal, sama seperti eritromisin bahwa antibiotik sefadroksil tidak boleh diberikan pada pasien yang hipersensitivitas terhadap sefalosporin dan pasien dengan gangguan fungsi ginjal (Adnyana et al., 2008).

Pada kasus yang terjadi di Puskesmas Olak Kemang bahwa pemberian ciprofloksasin dikatakan tidak tepat pasien dikarenakan menurut literatur bahwa obat ini seharusnya dihindari penggunaannya pada anak $<12$ tahun yang masih dalam masa pertumbuhan dan belum pubertas, karena dapat menimbulkan anoreksia, depresi, ansietas, dan dermatitis (Adnyana et al., 2008).

Tabel 4. Hasil kerasionalan penggunaan antibiotik berdasarkan ketepatan indikasi

\begin{tabular}{lcccccc}
\hline \multirow{2}{*}{ No. } & \multirow{2}{*}{ Jenis Antibiotik } & Diagnosis & \multirow{2}{*}{ Jumlah kasus } & \multicolumn{2}{c}{ Tepat indikasi } & Persentase \\
\cline { 4 - 5 } & & & Tepat & Tidak Tepat & (\%) \\
\hline 1. & Amoksisilin & Faringitis & 33 & $\mathrm{~V}$ & 47,1 \\
2. & Amoksisilin & Tonsilitis & 27 & $\mathrm{~V}$ & 38,5 \\
3. & Eritromisin & Tonsilitis & 3 & $\mathrm{~V}$ & 4,2 \\
4. & Eritromisin & Faringitis & 2 & $\mathrm{~V}$ & 2,8 \\
5. & Amoksisilin & Otitis Media & 2 & $\mathrm{~V}$ & 2,8 \\
6. & Cefadroksil & Faringitis & 1 & $\mathrm{~V}$ & 1,4 \\
7. & Ciprofloksasin & Tonsilitis & 1 & $\mathrm{~V}$ & 1,4 \\
8. & Cefadroksil & Tonsilitis & 1 & $\mathrm{~V}$ & 1,4 \\
\hline Total & & & 70 & 70 & - & 100 \\
\hline
\end{tabular}


Dari Tabel 4 diketahui bahwa penggunaan antibiotik yang diberikan untuk diagnosa faringitis dan otitis media sudah tepat dan sesuai dengan standar Pharmaceutical Care tahun 2005, hanya untuk diagnosa tonsilitis dinilai kurang tepat dikarenakan sedikitnya informasi yang membahas tentang tonsilitis pada Pharmaceutical care tahun 2005 dan tidak ada panduan khusus dalam pemberian terapi untuk penyakit ini dan hanya beberapa antibiotik yang diindikasikan untuk tonsilitis.

Amoksisilin diketahui adalah antibiotik golongan penisilin dengan derivat $\beta$-laktam yang memiliki aksi bakterisidal dan indikasi terhadap infeksi saluran pernapasan, dengan mekanisme kerjanya menurut Katzung (2014) yaitu dapat menghambat pertumbuhan bakteri dengan cara menganggu reaksi transpeptidasi sintesis dinding sel bakteri. Dinding sel adalah lapisan luar yang rigid atau kaku pada setiap spesies bakteri, peptidoglikan merupakan suatu komponen dalam penyusun dinding sel ini. Bakteri gram positif memiliki dinding sel yang sangat tebal dan untuk bakteri gram negatif mempunyai lapisan peptidoglikan yang tipis.

Diketahui bahwa penyebab dari faringitis, tonsilitis, dan otitis media ini adalah bakteri dari gram positif maupun negatif. Jadi dengan pemberian antibiotik yang berspektrum luas seperti golongan penisilin dan sefalosforin yang mempunyai mekanisme kerja yaitu dapat menghambat reaksi ini, maka akan menghentikan sintesis peptidoglikan dan mematikan bakteri (Katzung, 2014).

Tabel 5. Hasil kerasionalan penggunaan antibiotik berdasarkan ketepatan pasien

\begin{tabular}{|c|c|c|c|c|c|c|c|c|}
\hline \multirow{2}{*}{ No. } & \multirow{2}{*}{ Kondisi Pasien } & \multirow{2}{*}{$\begin{array}{c}\text { Jenis } \\
\text { Antibiotik }\end{array}$} & \multirow{2}{*}{$\begin{array}{c}\text { Jumlah } \\
\text { Kasus }\end{array}$} & \multicolumn{2}{|c|}{ Kontra Indikasi } & \multicolumn{2}{|c|}{ Tepat Pasien } & \multirow{2}{*}{$\begin{array}{c}\text { Persentase } \\
\text { (\%) }\end{array}$} \\
\hline & & & & Ya & Tidak & Tepat & Tidak Tepat & \\
\hline \multirow[t]{4}{*}{1.} & (-) alergi obat dan & AMX & 64 & & $\sqrt{ }$ & $\sqrt{ }$ & & 91,4 \\
\hline & riwayat penyakit & ERT & & & & & & \\
\hline & & CFD & & & & & & \\
\hline & & CPR & & & & & & \\
\hline 2. & $\begin{array}{l}\text { (-) alergi obat, ada } \\
\text { riwayat penyakit } \\
\text { lambung/Maag }\end{array}$ & AMX & 4 & & $v$ & v & & 5,7 \\
\hline 3. & $\begin{array}{l}\text { (-) alergi obat, ada } \\
\text { riwayat penyakit } \\
\text { lambung/Maag }\end{array}$ & ERT syr & 1 & & $\checkmark$ & $\checkmark$ & & 1,4 \\
\hline \multirow[t]{2}{*}{4.} & $(-)$ alergi obat dan & & & & & & & \\
\hline & riwayat penyakit & CPR & 1 & $\sqrt{ }$ & & & $\sqrt{ }$ & 1,4 \\
\hline Total & & & 70 & 1 & 69 & 69 & 1 & 100 \\
\hline
\end{tabular}

Keterangan: Tepat pasien=69 kasus $(98,5 \%)$, tidak tepat pasien=1 kasus $(1,4 \%), A M X=a m o k s i s i l i n$, $\mathrm{ERT}=$ eritromisin, $\mathrm{CFD}=$ cefadroksil, $\mathrm{CPR}=$ ciprofloksasin.

Untuk golongan makrolida seperti eritromisin, memiliki mekanisme kerja yaitu menghambat sintesis protein pada bakteri, dengan cara berikatan 
atau menempel pada subunit 50s ribosom bakteri dan mencegah pembentukan ikatan peptida dengan menghambat enzim peptidil transferase sehingga menghambat langkah translokasi sintesis protein bakteri (Mycek et al., 2001). Sedangkan, pada antibiotik dari golongan kuionolon yaitu dapat mempengaruhi sintesis atau metabolisme dari asam nukleat.

Pada penyakit tonsilitis, antibiotika yang dapat diberikan adalah golongan penisilin atau sulfonamida, namun bila terdapat alergi pada penggunaan penicillin dapat diberikan eritromisin atau klindamisin. Ada juga dari hasil penelitian yang dilakukan di RSUP Prof. DR. R.D Kandou Manado bahwa penanganan tonsilitis dapat diberikan antibiotik dari golongan penisilin, sefalosporin, klindamisin, dan kuinolon (Palandeng et al., 2014). Jadi, dalam penggunaannya jenis antibiotik amoksisilin ini sudah sesuai diberikan untuk pasien yang didiagnosa tonsillitis namun pada standar tidak tertera.

Tabel 6. Hasil kerasionalan penggunaan antibiotik berdasarkan ketepatan obat

\begin{tabular}{|c|c|c|c|c|c|c|c|}
\hline \multirow{2}{*}{ No. } & \multirow{2}{*}{ Diagnosis } & \multirow{2}{*}{$\begin{array}{c}\text { Antibiotik } \\
\text { yang diberikan }\end{array}$} & \multirow{2}{*}{$\begin{array}{c}\text { Antibiotik } \\
\text { sesuai Standar }\end{array}$} & \multirow{2}{*}{$\begin{array}{c}\text { Jumlah } \\
\text { Kasus }\end{array}$} & \multicolumn{2}{|c|}{ Tepat Obat } & \multirow{2}{*}{$\begin{array}{c}\text { Persentase } \\
\text { (\%) }\end{array}$} \\
\hline & & & & & Tepat & Tidak Tepat & \\
\hline 1. & FA & AMX, ERT, CFD & $\begin{array}{l}\text { PNC, AMX, } \\
\text { ERT, AZT, Gol. } \\
\text { sefalosporin } \\
\text { gen } 1 \text { atau } 2\end{array}$ & 36 & $\sqrt{ }$ & & 51,4 \\
\hline 2. & TO & $\begin{array}{l}\text { AMX, ERT, } \\
\text { CPR, CFD }\end{array}$ & AZT, CFRK & 32 & & $\checkmark$ & 45,7 \\
\hline 3. & OTM & AMX & $\begin{array}{l}\text { AMX, } \\
\text { KTRMZ, CFRK, } \\
\text { CFTX, CFPZ, } \\
\text { CFXM }\end{array}$ & 2 & v & & 2,8 \\
\hline Total & & & & 70 & 38 & 32 & 100 \\
\hline
\end{tabular}

Keterangan: Standar=Pharmaceutical Care tahun 2005 tentang Infeksi Saluran Pernapasan, tepat obat $=38$ kasus $(54,2 \%)$, tidak tepat obat $=32$ kasus $(45,7 \%)$, FA faringitis, TO=tonsilitis, OTM=otitis media, $A M X=$ amoksisilin, $\quad E R T=$ eritromisin, $\mathrm{CFD}=$ cefadroksil, $\quad \mathrm{CPR}=$ ciprofloksasin, $\quad \mathrm{PNC}=$ penicillin, $\quad \mathrm{AZT}=$ azitromisin,

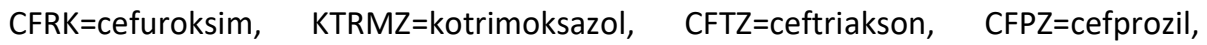
CFXM=cefiksim.

Hasil kerasionalan penggunaan antibiotik berdasarkan ketepatan dosis disajikan pada Tabel 7. Dalam penggunaan antibiotik terutama pada anak tentu harus memperhatikan bagaimana ketepatan dosisnya dan disesuaikan dengan umur atau berat badan anak. Evaluasi ketepatan dosis ini dinilai berdasarkan frekuensi dan durasi pemberian lalu disesuaikan dengan dosis lazim yang yang diacu dalam buku standar Pharmaceutical Care tahun 2005. 
Vol.17 No. 01 Juli 2020:158-171

Tabel 7. Hasil kerasionalan ketepatan regimen dosis berdasarkan frekuensi pemberian

\begin{tabular}{|c|c|c|c|c|c|c|c|}
\hline \multirow{2}{*}{ No. } & \multirow{2}{*}{ Diagnosis } & \multirow{2}{*}{$\begin{array}{c}\text { Nama } \\
\text { Obat }\end{array}$} & \multicolumn{2}{|c|}{ Frekuensi pemberian } & \multirow{2}{*}{$\begin{array}{c}\text { Jumlah } \\
\text { Kasus }\end{array}$} & \multirow{2}{*}{ Ket } & \multirow{2}{*}{$\begin{array}{c}\text { Persentase } \\
\text { (\%) }\end{array}$} \\
\hline & & & Pasien & Sesuai Standar & & & \\
\hline 1. & FA & AMX & $3 \times 250 \mathrm{mg}$ & $3 \times 250 \mathrm{mg}$ & 14 & TD & 20 \\
\hline 2. & TO & AMX & $3 \times 250 \mathrm{mg}$ & $\begin{array}{c}25-50 \mathrm{mg} / \mathrm{kg} / \text { hari } \\
\text { dalam } 3 \text { dosis } \\
\text { terbagi }\end{array}$ & 14 & TD & 20 \\
\hline 3. & FA & AMX & $3 \times 500 \mathrm{mg}$ & $3 \times 250 \mathrm{mg}$ & 11 & DB & 15,7 \\
\hline 4. & TO & AMX & $3 \times 500 \mathrm{mg}$ & $\begin{array}{c}25-50 \mathrm{mg} / \mathrm{kg} / \text { hari } \\
\text { dalam } 3 \text { dosis } \\
\text { terbagi }\end{array}$ & 8 & DB & 11,4 \\
\hline 5. & TO & AMX & $3 \times 500 \mathrm{mg}$ & $\begin{array}{c}25-50 \mathrm{mg} / \mathrm{kg} / \text { hari } \\
\text { dalam } 3 \text { dosis } \\
\text { terbagi }\end{array}$ & 4 & TD & 5,7 \\
\hline 6. & FA & $\begin{array}{l}\text { AMX } \\
\text { syr }\end{array}$ & $3 \times 125 \mathrm{mg}$ & $3 \times 250 \mathrm{mg}$ & 4 & DK & 5,7 \\
\hline 7. & FA & $\begin{array}{c}\text { AMX } \\
\text { syr }\end{array}$ & $3 \times 375 \mathrm{mg}$ & $3 \times 250 \mathrm{mg}$ & 3 & DB & 4,2 \\
\hline 8. & TO & ERT syr & $3 \times 200 \mathrm{mg}$ & $\begin{array}{c}2-4250-500 \mathrm{mg} \\
30-50 \mathrm{mg} / \mathrm{kg} \\
\text { terbagi dalam } 3 \\
\text { dosis }\end{array}$ & 3 & DK & 4,2 \\
\hline 9. & TO & $\begin{array}{c}\text { AMX } \\
\text { syr }\end{array}$ & $3 \times 125 \mathrm{mg}$ & $\begin{array}{c}25-50 \mathrm{mg} / \mathrm{kg} / \text { hari } \\
\text { dalam } 3 \text { dosis } \\
\text { terbagi }\end{array}$ & 2 & TD & 2,8 \\
\hline 10. & FA & ERT syr & $3 \times 200 \mathrm{mg}$ & $4 \times 250 \mathrm{mg}$ & 2 & DK & 2,8 \\
\hline 11. & OTM & AMX & $3 \times 500 \mathrm{mg}$ & $\begin{array}{c}20-40 \mathrm{mg} / \mathrm{kg} / \text { hari } \\
\text { terbagi dalam } 3 \\
\text { dosis }\end{array}$ & 2 & DB & 2,8 \\
\hline 12. & TO & CFD & $2 \times 500 \mathrm{mg}$ & $\begin{array}{c}30 \mathrm{mg} / \mathrm{kg} / \mathrm{hari} \\
\text { terbagi dalam } 2 \\
\text { dosis }\end{array}$ & 1 & DB & 1,4 \\
\hline 13. & FA & CFD & $2 \times 500 \mathrm{mg}$ & $\begin{array}{c}30 \mathrm{mg} / \mathrm{kg} / \mathrm{hari} \\
\text { terbagi dalam } 2 \\
\text { dosis }\end{array}$ & 1 & DB & 1,4 \\
\hline
\end{tabular}

$\begin{array}{lllllll}\text { 14. TO } & \text { CPR } & 2 \times 250 \mathrm{mg} & 2 \times 500-750 \mathrm{mg} & 1 & \text { DK } & 1,4\end{array}$

Total $\quad 70 \quad 100$

Keterangan: Standar=Pharmaceutical Care tahun 2005 tentang Infeksi Saluran Pernapasan, $\mathrm{TD}=$ tepat dosis 34 kasus $(48,5 \%), \mathrm{DB}=$ dosis berlebih 24 kasus $(34,1 \%), \mathrm{DK}=$ dosis kurang 12 kasus $(16,9 \%), F A=$ faringitis, TO=tonsilitis, OTM=otitis media, $\mathrm{AMX}=$ amoksisilin, $\mathrm{ERT}=$ =eritromisin, $\mathrm{CFD}=$ cefadroksil, $\mathrm{CPR}=$ ciprofloksasin

Dari hasil didapatkan bahwa berdasarkan frekuensi pemberian, terdapat 34 dari 70 pasien yang pemberian antibiotik sudah sesuai dengan standar pengobatan. Sedangkan, ada 24 pasien yang mendapatkan dosis berlebih dan 12 pasien lainnya mendapatkan obat namun dosisnya kurang. Perhitungan dosis obat yang sesuai dapat memaksimalkan kerja obat sehingga efek terapi yang diinginkan dapat 
tercapai. Penggunaan obat dengan dosis kurang dari yang dibutuhkan dapat mengakibatkan pasien mengalami resistensi bakteri yang tersisa di dalam tubuh, sedangkan jika dosis berlebih akan menimbulkan efek samping yang tidak diharapkan (Nisa, 2017).

Adapun dalam menentukan ketepatan dosis juga dilihat dari frekuensi pemberian obat dan disesuaikan pada standar Pharmaceutical care tahun 2005. Frekuensi pemberian akan meningkatkan dan mempengaruhi kepatuhan pasien dalam minum obat, ketidaktepatan frekuensi pemberian antibiotik akan mempengaruhi kadar obat di dalam darah.
Frekuensi penggunaan obat
salah satunya dipengaruhi dari
farmakokinetika obat itu sendiri misalnya tiap 4, 6, 8, 12, atau 24 jam. Jika kadar obat di dalam tubuh habis dalam waktu 8 jam, sebaiknya obat diminum 3 kali sehari begitu juga seterusnya jika kadar obat akan habis dalam waktu 12 jam sebaiknya obat diminum 2 kali sehari. Adapun tujuan frekuensi pemberian obat adalah untuk menjaga konsentrasi obat dalam cairan plasma agar selalu berada pada titik konsentrasi terapetik minimal sehingga obat dapat memberikan efek yang diinginkan dan masih dalam batas toleransi (Fajarwati, 2013).

Tabel 8. Hasil kerasionalan ketepatan regimen dosis berdasarkan durasi pemberian

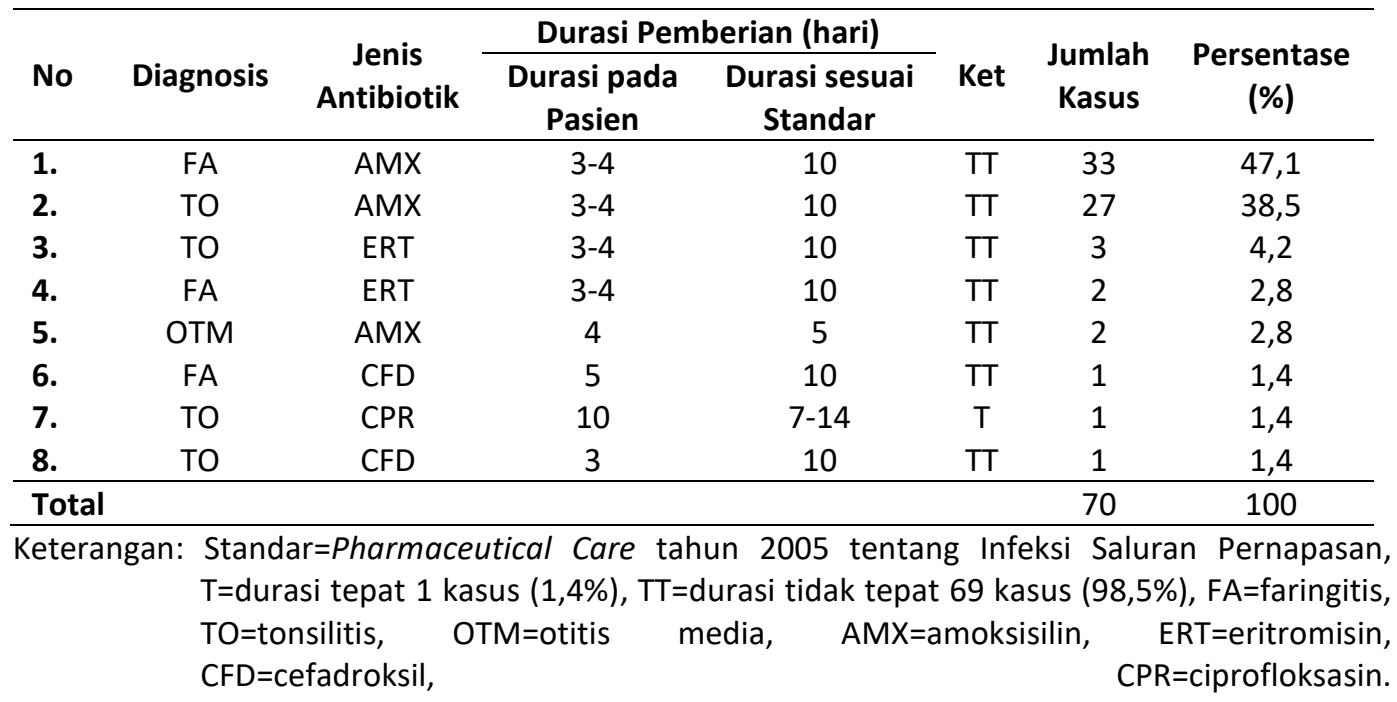

Beberapa antibiotik juga kontraindikasi terhadap penderita gangguan ginjal atau fungsi hati, hal ini berkaitan dengan proses eliminasi obat. Jika organ ginjal atau hati telah mengalami gangguan atau kerusakan, maka obat akan lambat atau sulit untuk dieliminasi dari dalam tubuh.

Menurut pedoman Pharmaceutical care tahun 2005, bahwa 
untuk durasi pemberian antibiotik diagnosa otitis media yaitu selama 5 hari, sedangkan untuk faringitis yaitu selama 10 hari, dan tonsilitis selama 714 hari. Dari hasil penelitian, hanya 1 dari 70 kasus yang durasi pemberian antibiotiknya sudah sesuai dengan standar yaitu untuk diagnosa tonsillitis dan diberikan antibiotik ciprofloksasin. Masih banyak pemberian antibiotik yang tidak sesuai dengan acuan, ratarata durasi pemberian antibiotik hanya berkisar 3-4 hari. Jika durasi pemberian obat yang terlalu singkat tentu akan berpengaruh juga terhadap hasil pengobatan yang didapatkan kemungkinan yang terjadi infeksi tidak teratasi dengan baik.

\section{Simpulan}

Berdasarkan hasil penelitian dapat disimpulkan bahwa kasus ISPA yang terjadi di Puskesmas Olak Kemang pada tahun 2018 didominasi oleh anak laki-laki berjumlah 41 pasien $(58,5 \%)$ dengan rentang usia 5-8 tahun $(77,1 \%)$. Sedangkan penggunaan antibiotik terbanyak dari golongan penisilin yaitu amoksisilin (88,5\%) dengan parameter ketepatan indikasi (100\%), ketepatan pasien $(98,5 \%)$, ketepatan obat $(54,2 \%)$, ketepatan dosis berdasarkan frekuensi pemberian (48,5\%), dan durasi pemberian $(1,4 \%)$.

\section{Daftar Pustaka}

Adnyana, I.K., Andrajati, R., Setiadi, A. P., Sigit, J.I., Sukandar, E.Y. 2008. ISO Farmakoterapi. Jakarta: PT. ISFI Penerbitan.
Agrina, A., Suyanto, S., Arneliwati, A. 2014. Analisa aspek balita terhadap kejadian infeksi saluran pernafasan akut (ISPA) di rumah. Jurnal Keperawatan, 5(2):115-120.

Depkes RI. 2005. Pharmaceutical Care untuk Penyakit Infeksi Saluran Pernapasan. Jakarta: Depkes RI.

Fajarwati, A.H. 2013. Evaluasi penggunaan antibiotika pada penyakit infeksi saluran pernafasan akut kelompok pediatri di Instalasi Rawat Inap Rumah Sakit Panti Rapih Yogyakarta. Skripsi. Fakultyas Farmasi, Universitas Sanata Dharma, Yogyakarta.

Iskandar, A., Tanuwijaya, S., Yuniarti, L. 2015. Hubungan jenis kelamin dan usia anak satu tahun sampai lima tahun dengan kejadian infeksi saluran pernapasan akut (ISPA). Global Medical \& Health Communication, 3(1):1-6.

Katarnida, S.S., Karyanti, M.R., Oman, D.M., Katar, Y. 2016. Pola sensitifitas bakteri dan penggunaan antibiotik. Sari Pediatri, 15(2):122-126.

Katzung, B.G. 2014. Farmakologi Dasar \& Klinik. Vol. 2. Edisi $12^{\text {th }}$. Jakarta: Penerbit Buku Kedokteran EGC.

Kemenkes RI. 2011. Pedoman Pengendalian Infeksi Saluran Pernapasan Akut. Jakarta: Kemenkes RI, Dirjen Pengendalian Penyakit dan Penyehatan Lingkungan. 
Maharani, D., Yani, F.F., Lestari, Y. 2017. Profil Balita Penderita Infeksi Saluran Nafas Akut Atas di Poliklinik Anak RSUP DR. M. Djamil Padang Tahun 20122013. Jurnal Kesehatan Andalas, 6(1):152-157.

Mycek, M.J, Harvey, R.A., Champe, P. 2001. Farmakologi Ulasan Bergambar (Kedua). Jakarta: Widya Medika.

Nisa, D.N. 2017. Evaluasi penggunaan antibiotik pada penyakit infeksi saluran pernapasan atas (ISPA) anak di Instalasi Rawat Jalan Rsud Dr. Moewardi Tahun 2015. Skripsi. Fakultas Farmasi, Universitas Muhammadiyah Surakarta.

Notoatmodjo, S. 2010. Metodologi Penelitian Kesehatan. Jakarta: Rineka Cipta.

Palandeng, A.C.T., Tumbel, R.E.C., Dehoop, J. 2014. Penderita tonsilitis di poliklinik THT-KL BLU RSUP Prof. Dr. R. D. Kandou
Manado Januari 2010Desember 2012. E-CliniC, 2(2):2-6.

Ramadhan, F., Sahrudin, S., Ibrahim, K. 2017. Analisis faktor risiko kejadian tonsilitis kronis pada anak usia 5-11 tahun di wilayah kerja Puskesmas Puuwatu Kota Kendari Tahun 2017. Jurnal IImiah Mahasiswa Kesehatan Masyarakat Unsyiah, 2(6): 198127.

Sani, F. 2016. Metodologi Penelitian Farmasi Komunitas dan Eksperimental. Yogyakarta: Penerbit Deepublish.

Setiyaningrum, E. 2017. Tumbuh Kembang Anak Usia 0-12 Tahun. Sidoarjo: Indomedia Pustaka.

Suyami, Sunyoto. 2006. Karakteristik faktor resiko ISPA pada anak usia balita di Puskesmas Pembantu Krakitan, Bayat, Klaten. Jurnal Ilmu Kesehatan, 1(2):1-19. 